\title{
Variasi Morfologi Empat Spesies Jati ( Tectona Sp) di Asia Tenggara: Potensi Pemuliaan Pohon dan Bioteknologinya
}

\section{Morphology Variation Of Four Teak Species (Tectona Sp) In Southeast Asia: The Potential Of Tree Breeding And Its Biotechnology}

\author{
Mohamad Anis Fauzi ${ }^{1}$, Tri Maria Hasna ${ }^{1}$, Dedi Setiadi ${ }^{1}$,Hamdan Adma Adinugraha ${ }^{1}$ \\ ${ }^{1}$ Balai Besar Penelitian dan Pengembangan Bioteknologi dan Pemuliaan Tanaman Hutan \\ Jl. Palagan Tentara Pelajar KM 15, Sleman, Yogyakarta, Indonesia \\ Email:manisfauzi76@gmail.com_*Penulis Korespondensi
}

\begin{abstract}
Knowledge of teak plant morphological variations and their use for biotechnology and breeding activities is still around one species, namely Tectona grandis. While other species such as Tectona abludens, Tectona hamiltoniana and Tectona philiphinensis are not widely known. The study was conducted to examine the character of several teak plant species by taking leaf samples from three teak plant development sites in Java, namely Cepu and Randublatung (Central Java), Nglambangan, Bojonegoro (East Java), and Ciamis (West Java). For Tectona abludens species, leaf samples were taken in Yogyakarta Special Region, namely in Dlingo, Bantul and Selang, Gunungkidul. Leaf samples of each type were taken 2 leaves (young leaves and old leaves) with 5 replications. As for the type of Tectona philiphinensis, it is further studied based on information obtained from the Ministry of Forestry of the Philippines. Meanwhile, the Tectona hamiltoniana type is equipped with data and information from the Ministry of Forestry of Myanmar. Tectona grandis has a morphology that is closer to Tectona abludens, while Tectona hamiltoniana and Tectona phillipinensis have a distinctive morphology that is different from the others. Some of the morphological characters of the four species have the opportunity to be used for teak tree breeding, including stem straightness, adaptability in dry land and resistance to disease.
\end{abstract}

Keywords: morphological variation, tree breeding, biotechnology, species, Tectona sp

\begin{abstract}
Abstrak
Pengetahuan mengenai variasi morfologi tanaman Jati dan pemanfaatannya untuk kegiatan bioteknologi dan pemuliaan masih berkisar pada satu spesies saja yaitu Tectona grandis. Sedangkan spesies lain seperti Tectona abludens, Tectona hamiltoniana dan Tectona philiphinensis belum banyak diketahui. Penelitian dilakukan untuk mengkaji karakter beberapa spesies tanaman jati dengan mengambil sampel daun di tiga lokasi pengembangan tanaman Jati di Pulau Jawa yaitu Cepu dan Randublatung (Jawa Tengah), Nglambangan, Bojonegoro (Jawa Timur), dan Ciamis (Jawa Barat). Untuk Spesies Tectona abludens sampel daun diambil di Daerah Istimewa Yogyakarta, yaitu di Dlingo, Bantul dan Selang, Gunungkidul. Sampel daun dari tiap jenis diambil 2 daun (daun muda dan daun tua) dengan 5 ulangan. Sedangkan untuk jenis Tectona philiphinensis lebih dalam dipelajari berdasarkan informasi yang diperoleh dari Kementrian Kehutanan Philipina. Sementara itu untuk jenis Tectona hamiltoniana dilengkapi dengan data dan informasi dari Kementrian Kehutanan Myanmar. Tectona grandis memiliki morfologi yang lebih dekat dengan Tectona abludens, sedangkan Tectona hamiltoniana dan Tectona phillipinensis memiliki morfologi khas yang berbeda dengan lainnya. Beberapa karakter morfologis dari keempat spesies tersebut berpeluang diamanfaatkan untuk kegiatan pemuliaan pohon Jati antara lain kelurusan batang, kemampuan adaptasi di lahan kering dan ketahanan terhadap penyakit.
\end{abstract}

Kata Kunci: variasi morfologi, pemuliaan pohon, bioteknologi, spesies, Tectona sp 


\section{Pendahuluan}

Tectona grandis memiliki sebaran alam yang luas tetapi terputus dari India, Myanmar, Laos, Kamboja dan Thailand. Sebaran jati di Asia Tenggara mulai dari $73^{\circ}-103^{\circ} \mathrm{BT}$ dari India melalui Myanmar ke Thailand dan Laos. Sebaran alam jati yang tumbuh di India Myanmar terletak pada $9^{\circ}-25^{\circ} \mathrm{LU}$ (Sastrosumarto dan Suhaendi,1985). Di Indonesia jenis ini mengalami proses naturalisasi sehingga mampu tumbuh dengan baik dalam lingkungan tanah, iklim dan curah hujan yang ada. Jati di Indonesia pada awalnya tumbuh sebagian besar di Pulau Jawa, Pulau Madura, Pulau Kangean, Sulawesi Tenggara, Pulau Muna dan Pulau Buton.

Saat ini tanaman Jati dikembangkan di berbagai wilayah di Indonesia antara lain di Aceh, Sumatera Utara, Lampung, Sulawesi Selatan, Sulawesi Tengah, Nusa Tenggara Barat-Timur, Maluku bahkan Papua. Secara internasional jati sudah dikenal secara luas, karena kualitas kayunya, kegunaan, kelas awet dan nilai ekonomi yang tinggi. Sehingga jenis ini dikembangkan di luar sebaran alaminya meliputi Indonesia, Malaysia, Bangladesh, Thailand, Afrika (Cote d'Ivore dan Nigeria) dan Amerika Selatan serta Amerika Tengah (Costa Rica, Trinidad, Tobago dan Brazil).

Tectona sp merupakan salah satu genus yang menghasilkan kayu yang baik untuk pertukangan dan kegunaan lainnya. Di dunia, genus Tectona terdapat 23 genera yang sebagian besar tanaman tersebut menghasilkan kayu. Di Indonesia Jati (Tectona sp) diperkirakan telah dibudidayakan sejak 800 tahun yang lalu (Midgley dkk., 2009) dan mengalami proses naturalisasi sehingga mampu tumbuh dengan baik pada iklim dan kondisi tanah setempat.

Indonesia mengelola hutan tanaman jati seluas \pm 1 juta ha, dimana luasan itu merupakan $31 \%$ dari total seluruh luasan hutan tanaman Jati yang ada di dunia yaitu 5,7 juta ha (Bhat and Ma, 2004). Jati telah lama dikenal di Indonesia sejak jaman dahulu dan dipergunakan kayunya untuk bahan rumah, jembatan, kapal kayu dan perahu. Jati memiliki peranan penting dalam kehidupan manusia karena memiliki kekuatan, keawetan dan mudah dalam pengerjaannya. Meskipun demikian, upaya pengelolaan, pemuliaan dan bioteknologinya lebih mendalam hanya dilakukan pada jenis Tectona grandis saja. Penelitian ini bertujuan untuk mengkaji variasi morfologi dari empat spesies Jati yang ada di Asia Tenggara serta memberikan informasi tentang potensi, dan peluang bioteknologi dan pemuliaan pohonnya.

\section{Metode Penelitian}

Penelitian ini dilakukan dengan mengambil sampel daun untuk jenis Tectona grandis di Jawa Tengah (Cepu dan Randublatung), di Jawa Timur (Nglambangan Bojonegoro) dan Jawa Barat (Ciamis) masingmasing lokasi 10 pasang daun. Jenis Tectona hamiltoniana diambil dari Cepu dan Randublatung sebanyak 10 pasang dan koleksi bijinya diperoleh dari Ministry of Forestry of Myanmar, sedangkan untuk Tectona abludens daun diambil dari pohon Desa Jatimulyo, Dlingo Bantul masing-masing 10 pasang daun. Tectona philippinensis didapatkan informasinya dari Ministry of Forestry Philipine karena di Indonesia belum ada yang melakukan penanaman jenis tersebut.

Penelitian dilaksanakan \pm 11 bulan (Februari 2015 - Januari 2016) dengan membandingkan morfologi daun keempat jenis jati tersebut. Pengamatan dan penelitian dilakukan pada parameter morfologi daun (bentuk daun, ukuran, pertulangan daun primer, pertulangan daun sekunder, duduk daun, jumlah duduk daun, bentuk pinggir daun dan ciri khusus lain yang hanya dimiliki spesies tersebut). Hasil pengamatan dan penelitian didokumentasikan serta dicatat untuk diperbandingkan pada tiap parameter morfologi. Data mengenai biji, bunga, musim pembungaan, bentuk batang, kulit batang dan lainnya disertakan untuk melengkapi data pengamatan morfologi daun jati.

\section{Hasil dan Pembahasan}

\section{Morfologi dan sebaran Jati (Tectona grandis)}

Pohon jati mampu tumbuh sampai mencapai tinggi 30-35 m pada tanah yang bersolum tebal dan subur. Jati menggugurkan daunnya pada musim kemarau untuk mengurangi penguapan. Pohon jati memiliki tajuk membulat, batang silindris, tinggi batang 
bebas cabang antara 10-20 m, pada bagian batang sering beralur. Kulit batang memiliki tebal $3 \mathrm{~mm}$ pada tanaman muda dan dapat mencapai $0,5-0,7 \mathrm{~cm}$ pada tanaman tua, berwarna coklat muda-keabuan.

Kayu teras berwarna coklat muda coklat tua atau coklat kemerahan, sedangkan kayu gubal berwarna coklat muda keputihan atau putih kekuningan (Hardjodarsono, 1984). Daun tunggal, bertangkai pendek, memiliki duduk daun berseling berhadapan, bentuk duduk daun elips-bulat telur, panjang daun antara 23-40 cm sedangkan lebar daun $11-21$ $\mathrm{cm}$. Daun yang masih muda (tunas) berwarna coklat kemerahan. Buah bertipe batu, memiliki bulu halus, inti tebal, memiliki 4 ruang biji (Steenis, 1978; Corner 1988 dalam Hidayat, 1998).

Bunga jati bersifat majemuk yang terbentuk dalam malai bunga (inflorescence) yang tumbuh terminal di ujung atau tepi cabang. Malai bunganya terdiri dari ratusan bunga kecil, berwarna putih dan berbulu halus. Bunga jati termasuk berumah satu, yaitu putik dan benang sari berada dalam satu bunga (monoceous). Bunga jati berdiameter $\pm 1 \mathrm{~cm}$ dan bersifat aktinomorfik, mahkota menyatu sebanyak 6-7 helai. Bentuk bunga berkarang tersusun seperti anak payung menggarpu. Kelopak bunga berbentuk jentera corong dengan tabung pendek, berwarna putih, kadang memiliki bentuk seperti bunga mawar (rose) dan leher tidak berambut.

Putik tersusun dari bakal buah, memiliki empat buah bakal biji dan tangkai putik dengan kepala putik (stigma) yang bertiang. Tangkai putik dan benangsari (stamen) masing-masing memiliki panjang 6 $\mathrm{mm}$, diameter mahkota bunga $6-8 \mathrm{~mm}$. Gugus-gugus bunga bunga jati merekah tak lama setelah fajar.

Masa penyerbukan bunga jati yang terbaik terjadi di sekitar tengah hari, setiap bunga hidup hanya membuka selama satu hari. Bila tidak terjadi pembuahan, bunga akan gugur pada sore hari atau keesokan paginya. Jenis penyerbukan pada jati merupakan penyerbukan silang (Kaosa-ard, 1998). Jati merupakan jenis yang penyerbukannya terutama dilakukan oleh serangga tetapi ada juga yang melalui angin. Penyerbukan bunga dilakukan oleh banyak serangga, tetapi terutama oleh jenis-jenis lebah. Oleh karena itu, penduduk sekitar hutan juga sering dapat memanen madu lebah dari hutan-hutan jati.

Jati umumnya mulai berbunga umur 6 - 8 tahun setelah ditanam, tetapi pembungaan pertama bisa lebih awal, umur 3-4 tahun, dan bisa juga lebih lambat, umur 20-25 tahun. Kebiasaan awal pembungaan menyebabkan berkembangnya percabangan menggarpu. Jati berbunga pada musim hujan. Awal pembungaan terjadi kira-kira satu bulan setelah hujan pertama turun. Jati selalu berbunga setiap tahun, tetapi terjadi variasi besar dalam intensitas pembungaan setiap tahunnya (Rachmawati et al, 2002). Waktu pembungaan bervariasi tergantung pada datangnya musim hujan. Awal Pembungaan di wilayah Asia Selatan dan Asia Tenggara biasanya terjadi pada bulan Juni-Juli dan berlangsung sampai dengan bulan Oktober-Desember (Kaosa-ard, 1998).

\section{Morfologi dan sebaran Jati Kluwih (Tectona abludens)}

Jati Kluwih tersebar dan ditemukan secara acak di hutan jati Pulau Jawa, terutama di daerah Desa Jati Mulyo Kecamatan Dlingo, Bantul dan Selang, Gunungkidul Yogyakarta. Tectona abludens ditemukan oleh Santi dan Rudjiman, sekitar tahun 1991 serta diajukan menjadi species baru genus Tectona. Hasil koleksi herbarium Tectona abludens yang ditemukan di Dlingo dan Selang Yogyakarta dibandingkan dengan koleksi genus Tectona yang lain di Herbarium Kew London,Linnaean Society Herbarium London, Herbarium Bogor dan Herbarium Universitas Leiden Belanda. Informasi dari keempat tempat tersebut dinyatakan, bahwa belum terdapat specimen koleksi Tectona abludens seperti yang telah ditemukan oleh Santi dan Rudjiman. Hal ini mendorong Rudjiman, untuk mengusulkan hasil temuan spesies baru ini dengan usulan nama latin Tectona abludens.

Jati ini memiliki nama lokal Jati Kluwih karena daunnya bergelombang sehingga mirip dengan Kluwih (Artocarpus incise) atau Sukun (Artocarpus altilis). Pohon Jati Kluwih di lapangan dapat mencapai ketinggian 10-20 m, tajuk cenderung bercabang banyak dan berbentuk payung membulat.

Batang berwarna coklat keputihan, tebal kulit batang 0,8-1 cm, dan mengelupas 
tipis. Batang kayu berbentuk membulat sampai oval, dengan tinggi bebas cabang $4-7 \mathrm{~m}$ pada tinggi total $15 \mathrm{~m}$. Daun jati kluwih pada bagian pinggir daun berkelak-kelok atau bergelombang sehingga tampak tidak rata. Pada beberapa sampel daun yang diambil ada yang daunnya menjari menyerupai daun sukun atau kluwih. Permukaan daun lebih halus bila dibandingkan dengan daun jati umumnya.

Berdasarkan deskripsi yang dilakukan oleh Santi dan Rudjiman, jenis Tectona abludens paling tidak memiliki beberapa perbedaan dengan Tectona grandis, antara lain: bentuk daun, penampang pohon, bentuk kulit kayu, panjang petiole, bentuk pinggir daun, ukuran ovary dan bentuk epidermis (Rudjiman, 1991).

Sesuai hasil deskripsi morfologi dan dendrologi Rudjiman (1991) disimpulkan bahwa berdasarkan atas perbedaan bentuk daun yang stabil pada Tectona abludens, jenis tersebut dibedakan menjadi dua varietas yaitu Tectona abludens var. lacerate dan Tectona abludens var. abludens.

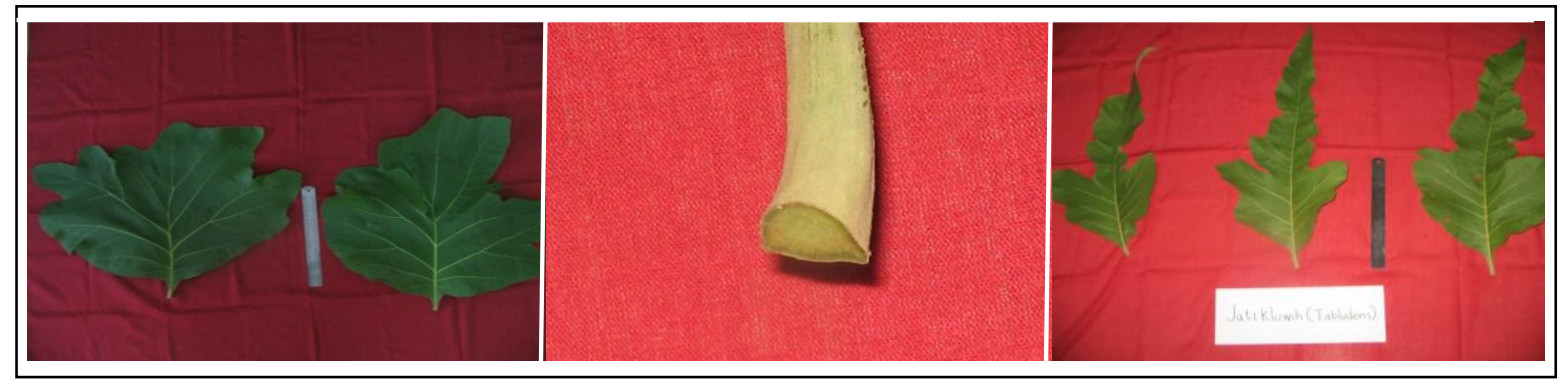

Gambar 1. Bentuk daun dan bentuk tangkai daun Jati Kluwih (Tectona abludens)

Keberadaan Jati Kluwih ini ditemukan dan diidentifikasi pertama kali oleh Santi dan Rudjiman sebagai jenis jati yang memiliki perbedaan dengan jati biasa (Tectona grandis). Sampai saat ini jenis ini belum dikembangkan dalam skala penanaman yang luas, hanya ditemukan tersebar pada daerah disekitar hutan jati. Jumlah pohon di habitat alam yang sangat terbatas menyebabkan upaya konservasi Tectona abludens perlu segera dilakukan. Berdasarkan pengamatan, paling tidak selain di Dlingo dan Selang, Tectona abludens di tanam di Arboretum Pusbanghut Perhutani Cepu, Wanagama UGM Gunungkidul dan Kampus Instiper Maguwoharjo.

\section{Morfologi dan sebaran Jati Dahat (Tectona hamiltoniana)}

Tectona hamiltoniana merupakan jenis jati yang secara alami terdapat di Myanmar dengan sebaran sempit (Prosea,1994). Tumbuh sampai pada ketinggian $660 \mathrm{~m}$ dpl. Dikenal dengan nama lokal Dahat teak, merupakan jenis yang toleran, mampu tumbuh di daerah yang kering (curah hujan kurang dari 40 inci/tahun) dan tidak subur bahkan pada lahan yang berbatu. Jenis jati ini merupakan indigenous species yang memiliki sebaran di Myanmar bagian tengah (daerah Yezin).
T.hamiltoniana biasanya tumbuh di hutan bersama-sama dengan jenis tanaman Than (Terminalia olliverii) dan Acacia sp. Kegunaan kayunya oleh masyarakat setempat sebagian besar untuk kayu energi (kayu bakar) (2009, Zaw Win pers.com). Keberadaan jenis ini sangat jarang dijumpai overlap dengan $T$. grandis (Hedegart, 1978).

Jati ini memiliki ciri berduduk daun tiga, tidak seperti famili Lamiaceae lainnya yang memiliki dua pasang duduk daun berselingan. Jenis ini mempunyai tiga daun pada setiap pasang duduk daunnya, berbatang lurus, tinggi bebas cabang yang tinggi dan mampu tumbuh di daerah kering.

Jati Dahat merupakan jenis yang menggugurkan daun, mempunyai ukuran pohon yang sedang dengan ketinggian kurang lebih 10-15 m dan mampu mencapai diameter kurang lebih $50-70 \mathrm{~cm}$. Bagian ranting yang muda berbulu halus. Berbeda dengan $T$. grandis yang memiliki bentuk cabang muda bersegi empat, $T$. hamiltoniana bentuk cabang mudanya bersegi 6-9 dengan kelopak buah tidak menggembung (Tewari, 1992) Duduk daun pada umumnya terdiri dari 3 helaian daun, kadang terdiri dari 4 helaian daun kadang bersilang berhadapan seperti pada $\mathrm{T}$. grandis tetapi mempunyai ukuran yang lebih kecil. Ukuran helaian daun 10-20 cm, tangkai 
daun 1,5-2 cm. Bunga berukuran kecil berwarna biru pucat atau putih. Ujung malai bunganya berbulu halus $(15-30 \mathrm{~cm})$. Mahkota bunga berukuran $8 \mathrm{~mm}$ dan berbulu lebat pada bagian leher (corolla throat). Periode berbunga pada bulan Juni-Agustus. Buah masak setelah musim dingin atau musim panas. Drupe berukuran kecil $(8 \mathrm{~mm})$, terdiri dari 4 biji tanpa rongga di bagian tengah, terbungkus rapat dalam calyx yang berbulu halus (Hedegart, 1978). Memiliki biji yang kecil berdiameter 1 $-1,5 \mathrm{~mm}$ dengan panjang biji antara $0,2-0,5$ $\mathrm{cm}$. Berat benih T.hamiltoniana 100 butir $=$
2,53 gram, berwarna coklat muda, berkulit ari tipis dan berbulu halus pada buah bijinya.

Kayu jenis ini memiliki penampakan yang berbeda dengan T.grandis. Kayu gubal berwarna putih kecoklatan atau putih pucat, sedangkan kayu teras berwarna coklat muda. Kayunya memiliki tekstur halus, keras dan lingkaran tumbuh yang jelas. Kayunya lebih berat, keras dan padat dibandingkan dengan T.grandis. kayu jenis ini juga memiliki daya resistensi yang tinggi terhadap serangan jamur dan rayap (Hedegart, 1978).

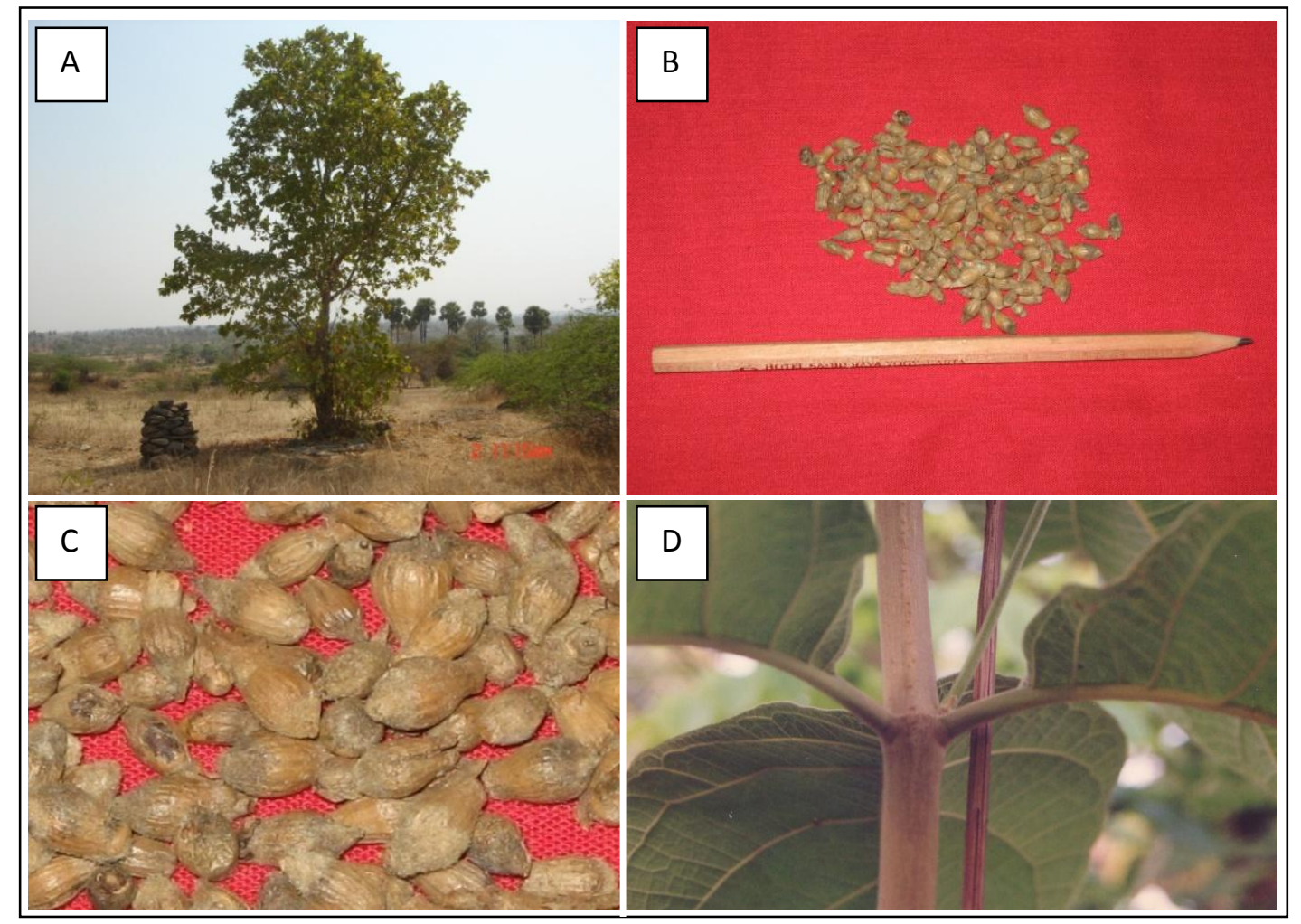

Gambar 2. A) Pohon Tectona hamiltoniana di Yezin Myanmar; B dan C) Bentuk dan ukuran biji; D) duduk daun.

Pengembangan Jati di Negara Myanmar hanya terbatas di daerah tertentu, tidak ditanam diseluruh area pengembangan tanaman jati, disebabkan karena T.hamiltoniana lebih cocok ditanam didaerah yang kering, curah hujan yang rendah dan suhu sekitar $32-35^{\circ}$ C. Karena sifatnya ini, penanaman dan perluasan areal T.hamiltoniana kurang berkembang dengan cepat. Kegiatan pengembangan yang dilakukan adalah lebih banyak kearah konservasi genetik pada jenis Tectona hamiltoniana .

\section{Morfologi dan sebaran Jati Philipina (Tectona philippinensis)}

Tectona philippinensis memiliki nama lokal yang bermacam-macam yaitu Philippine teak (umum), Bunglas (Panay Bisaya) dan Malapangit (Tagalog) (Prosea,1994). T.philippinensis ini merupakan jenis endemik lokal yang sebarannya hanya terdapat di Philippina, tersebar di Pulau Luzon dan Pulau Iling. Di Pulau Luzon terdapat di daerah Lobo dan San Juan, Propinsi Batangas, sedangkan di Pulau Iling ditemukan di daerah Katayungan dan Baclayon Barangays, 
Mindoro (Madulid, Agoo, \& Caringal, 2008). Jati Philipina ini memiliki sebaran dari pantai sampai hutan dataran rendah yang mengandung tanah kapur. Pada hutan semidecidous (menggugurkan daun saat musim kering) tanaman ini mendominasi dan mampu hidup berasosiasi dengan Terminalia polyalthia. Jenis tanaman lain yang berasosiasi dengan T.philippinensis yaitu Vitex parviflora, Asam (Tamaricus indicus), Mangga (Mangivera indica), Randu (Ceiba petandra), Syzygium sp, Parkia Roxburgii dan Beringin (Ficus sp).(Madulid, Agoo and Caringal, 2008).
Pohon relatif kecil dapat mencapai tinggi sampai $15 \mathrm{~m}$, diameter batang dapat mencapai $50 \mathrm{~cm}$ (Castaneto and Edmiston,2003) bentuk daun bulat telur sampai bulat memanjang, dimensi daun panjang 8-13 cm sedang lebar 3-6 cm. Panjang tangkai 5-7 $\mathrm{mm}$. Bunga memiliki panjang 8 $\mathrm{mm}$ dan berdiameter $10 \mathrm{~mm}$, calyx berbentuk corong, mahkota bunga berwarna putih dan berambut halus pada bagian corolla throat. Buah Tectona philippinensis dibungkus oleh calyx yang tidak menggelembung (Prosea, 1994), drupe berukuran sekitar $8 \mathrm{~mm}$. Kayunya digunakan untuk konstruksi bangunan dan mebel.

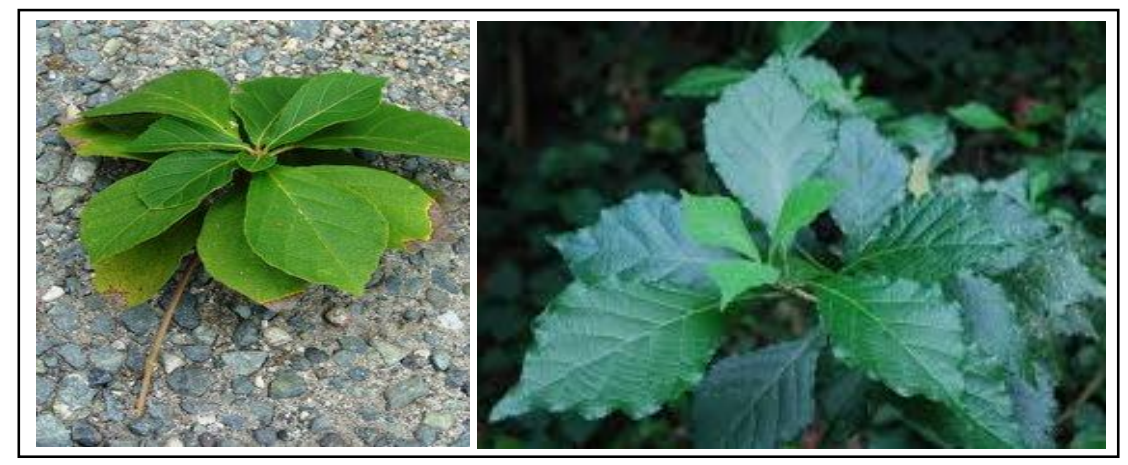

Gambar 3. Morfologi daun Jati Philipina (T. philippinensis).

Di Pulau Iling kemungkinan jumlah jenis ini kurang dari 100 batang, sedangkan di Batangas Pulau Luzon T. Philippinensis lebih melimpah. Habitat jenis ini di Pulau Luzon terfragmentasi dan keberadaannya semakin terancam karena pembangunan infrastruktur yang sedang berjalan di daerah tersebut sedangkan di kedua daerah tempat asalnya tidak dilindungi secara hukum. T.philippinensis yang tersisa semakin terancam keberadaannya karena kerusakan habitat, konversi dan pengembangan lahan. Oleh IUCN Tectona philippinensis ini memiliki status membahayakan ( $\mathrm{EN}=$ endangered) dalam kriteria B di tegakan alamnya. Program konservasi diperlukan untuk memapankan kembali jenis ini pada populasi alamnya yang stabil, baik konservasi in situ maupun ex situ.

\section{Potensi Pemuliaan Pohon dan Bioteknologi}

Tujuan dari pemuliaan pohon hutan adalah untuk memodifikasi (meningkatkan) rata-rata penampilan fenotipe dari sifat yang bernilai ekonomis tinggi (Finkeldey, 2005). Pemuliaan pohon merupakan upaya untuk meningkatkan mutu genetik tanaman melalui proses seleksi dan persilangan dengan memanfaatkan potensi yang dimiliki suatu jenis atau individu pohon. Pemuliaan pohon bekerja dengan adanya variasi/keragaman, sehingga dimungkinkan untuk mendapatkan peningkatan genetik yang tinggi sesuai dengan daerah pengembangan (Leksono, 2001). Potensi yang dimiliki oleh tanaman jati, merupakan modal dasar untuk mengembangkan program pemuliaan pohon. Potensi yang dimiliki tersebut berupa sebaran alam dan ras lahan yang luas, varietas atau tipe penampilan jati yang berbeda maupun variasi dari penampilan individu-individu pohonnya. Apabila ketiga potensi tersebut digabungkan, maka akan diperoleh keturunan atau benih unggul sesuai dengan yang diharapkan.

\section{a. Luas sebaran alami jati}

Jati memiliki sebaran alam yang cukup luas mulai dari India, Myanmar, Laos, Kamboja dan Thailand (Keiding et.al, 1986). Di Asia Tenggara memiliki sebaran alami dari India melalui Burma dan Thailand pada $9^{\circ}-$ $25^{\circ}$ LU (Sastrosumarto dan Suhaendi, 1985). Kemudian jati menyebar di Indonesia dan 
mengalami proses naturalisasi di pulau Jawa selama ratusan tahun. Dari Jawa, jati ditanam dan berkembang di pulau Kangenan, Madura, Sulawesi Tenggara, pulau Buton, pulau Muna, Bali dan NTT.

\section{b. Keragaman Pohon Jati}

Menurut Leksono (2001), program pemuliaan jati dapat dilakukan dengan memanfaatkan secara optimal tiga level variasi yang terdapat pada jati disebaran alamnya sebagai berikut:

\section{b.1. Variasi interspesifik}

Variasi jenis-jenis jati seperti tersebut di atas sering disebut dengan variasi interspesifik, yaitu variasi yang disebabkan karena adanya perbedaan kinerja antar spesies atau varietas sehingga dimungkinkan memperoleh suatu species atau varietas yang memiliki potensi tumbuh yang besar di suatu tapak pengembangan melalui uji species (species trial). Keragaman jenis tersebut merupakan modal dasar bagi pemuliaan untuk mendapatkan sifat-sifat unggul melalui persilangan. Persilangan antar spesies merupakan salah satu cara yang digunakan dalam meningkatkan keragaman genetik bahan pemuliaan. Keragaman tersebut nantinya akan diseleksi untuk mendapatkan varietas yang memiliki sifat unggul. Varietas bersifat unggul tersebut yang nantinya dapat dilepas sebagai varietas unggul.

\section{b.2.Variasi intraspesifik}

Selain variasi antar spesies jati seperti tersebut diatas, terdapat juga variasi intraspesies. Variasi ini muncul karena adanya perbedaan penampilan dan sifat-sifat yang dimiliki suatu jenis pada tingkat provenan atau ras lahan. Didalam jenis T. grandis menurut Hardjodarsono (1997) terdapat perbedaan berdasarkan sifat-sifat kayunya atau bentuk pohonnya antara lain:

Jati Lengo/jati Malam, kalau diraba halus seperti berminyak (tectochinon), kayunya keras dan berat. Berwarna gelap, banyak berbercak dan bergaris. Jati Sungu, memiliki kepadatan yang tinggi, kayu hitam (coklat gelap) dan berat. Jati Werut, kayunya keras dan seratnya berombak. Jati Doreng, berkayu sangat keras dengan warna loreng-loreng hitam menyala, sangat indah. Jati doreng lebih disebabkan adanya unsur Si (Silica) yang terserap dalam buluh kayu. Jati Kapur, warnanya keputih-putihan mengandung banyak kapur $\mathrm{CaCo} 3$ (calcium biphosphat). Kurang kuat dan kurang awet karena kayunya mudah pecah bontos saat penebangan.

Menurut batangnya dikenal pula yaitu: Jati Ri, dengan bintik-bintik/bisul seperti duri, Jati Pring, dengan gelang-gelang seperti buku-buku bambu, Jati Gembol, dengan adanya pembesaran batang abnormal yang mungkin disebabkan oleh suatu penyakit dan Jati Keyong, berbisul kecil-kecil yang mengelupas dan meninggalkan bekas lobang-lobang seperti kerang.

\section{b.3. Variasi Individu Pohon}

Variasi antar individu ini disebut dengan variasi intra provenansi dan intra famili, yaitu variasi yang disebabkan karena adanya perbedaan performa diantara individu pohon. Materi yang diperoleh dari individu terbaik dapat digunakan untuk program pemuliaan pohon tingkat lanjut, yaitu sebagai materi persilangan guna mendapatkan klonal unggul dengan kualitas genetik yang lebih tinggi dan karakteristik tertentu yang diinginkan.

Meskipun populasi alam Jati sangat penting untuk program pemuliaan, populasi tersebut mulai terancam keberadaannya. Ukuran populasi (areal hutan jati) menurun drastis karena beberapa faktor antara lain alih lahan untuk lahan pertanian, pemukiman, jalan dan lain-lain. Struktur genetik pada populasi yang tersisa juga terdegradasi dan terfragmentasi karena pembalakan yang tidak terkontrol. Meskipun populasi pertanaman pada level awal seleksi mempunyai kontribusi perolehan genetik (pertumbuhan) lebih besar dibandingkan dengan populasi alamnya, namun demikian populasi alam sangat penting untuk program seleksi dan breeding jangka panjang (Kaosa-ard, 1998). Tegakan alam $T$. grandis telah mengalami penurunan pada 50 tahun terakhir karena pembalakan liar dan lainlain yang menyebabkan kerusakan hutan. Jumlah T. philippinensis hanya tersisa 4300 spesimen hidup sedangkan spesimen $T$. hamiltoniana dan T. abludens belum diketahui namun keberadaannya terancam punah (Rivera,diakses 5 Agustus 2010 ).

Di Indonesia, sebagian besar hutan alam jati telah dibudidayakan dan dikonversi menjadi hutan tanaman sejenis, akibatnya struktur genetik populasinya menjadi lebih seragam (karena seleksi) daripada populasi 
India dan Asia lainnya. Menurut Kartadikara dalam Irwanto (2006) Observasi yang dilakukan pada $T$. grandis, di Indonesia menunjukkan bahwa dengan menggunakan 10 lokus alozim ditemukan bahwa jati di Indonesia memiliki keragaman genetik yang rendah dibanding jati India maupun Thailand. Sehubungan dengan itu konservasi plasma nutfah jati serta pertukaran materi genetik untuk memperluas basis genetik dari negara dengan sebaran alami jati menjadi hal yang sangat penting.

\section{Simpulan}

Tectona grandis memiliki morfologi yang lebih dekat dengan Tectona abludens, sedangkan Tectona hamiltoniana dan Tectona phillipinensis memiliki morfologi khas yang berbeda dengan lainnya. Beberapa karakter morfologis dari keempat spesies tersebut berpeluang dimanfaatkan untuk kegiatan pemuliaan pohon Jati antara lain kelurusan batang, kemampuan adaptasi di lahan kering dan ketahanan terhadap penyakit.

\section{Ucapan Terima Kasih}

Terima kasih diucapkan kepada: Puslitbang PERHUTANI Cepu; Prof. Dr. M. Naiem Fakultas Kehutanan UGM atas informasi mengenai pemuliaan Jati; Aris Wibowo, S.Hut, MP (Puslitbang PERHUTANI) atas informasi dan data mengenai varietas jati di Indonesia.

\section{Daftar Pustaka}

Bhat, K.M and Ma, Hwan O., 2004, Teak growers unite!, ITTO Tropical Forest Update Volume 14 No.1, Yokohama, Japan.

Castaneto, Y.T and Edmiston, Minda P.F, 2003. Response of Tectona philippinensis Benth. \& Hook (Philipine Teak) cutting to applied mykovam and biocore, Philippine Journal of Science, vol 132 (2) December 2003

Madulid, D.A., Agoo, E.M.G. \& Caringal, A.M. 2008. Tectona philippinensis, The IUCN Red List of Threatened Species 2008.
Midgley, Stephen dkk., 2009, Pilihan-pilihan untuk pengembangan industri kayu jati di Sulawesi Tenggara, Laporan Penelitian SADI-ACIAR no. Proyek SMAR/2007/229, Canberra, Australia.

Bhat,K.M. and Ok Ma,Hwan, 2004. Teak Growers unites, Tropical Forest Update volume 14 no.1, ITTO( International Tropical Timber Organization), Japan, Page 3-5.

Daryadi, L. 1959. Penyelidikan seleksi jati (Tectona grandis), Pengumuman No.70 Lembaga Penelitian Hutan, Bogor.

FAO, 2001. Global forest resources assesement 2000,FAO Forestry Paper no.140, Food and Agriculture Organization of the United Nation, Rome, Italy

Finkeldey, R. 2005. An Introduction to Tropical Forest Genetics (In Indonesian). Bogor : Fakultas Kehutanan IPB, Bogor.

Hardjodarsono. 1984. Jati, cetakan ke-4, Yayasan Pembina Fakultas Kehutanan, Universitas Gadjah Mada, Yogyakarta.

Hedegart, T. 1978. Data sheet species undergoing genetic improverishment. In : Data sheet on Tectona philippinensis Benth. \& Hook. Forest Genetic Resources No 8 Website:http://www.fao.org/docrep/006/17 530e/L7530E08.htm. Diakses tanggal 20 Oktober 2010.

Hedegart, T. 1978. Data sheet species undergoing genetic improverishment. In : Data sheet on Tectona hamiltoniana Wall. Forest Genetic Resources No 8. Website:http://www.fao.org/docrep/006/l7 530e/L7530E08.htm. Diakses tanggal 20 Oktober 2010.

Hidayat, A.1998. Evaluasi Awal Uji Klon dari 121 pohon Plus Jati (Tectona grandis L.f.) dengan Okulasi, Tesis Pascasarjana, Program Pascasarjana UGM, Yogyakarta (tidak diterbitkan).

Ko Ko Gyi, Mehm. 2009. Personal communication with Mehm Ko Ko Gyi, Forestry Department, Yangon Myanmar.

1991. In K.J. White. Proceedings of the China/ESCAP/FAO Regional Seminar on Research and Development of Teak. 19-27 March 1991

Kaosa-ard, A. 1998. Teak breeding and Improvement Straregies. In : Teak for The 
Future, Proceeding of the Second Regional Seminar on Teak 29 Mei-3 Juni 1995, Yangon, Myanmar. Thailand : FAO Regional Ofiice for Asia and The Pacific.

--, Suangtho V. and E.D. Kjaer. 1998. Experience from Tree Improvement of Teak (Tectona grandis) in Thailand, Danida Forest Seed Center, Humlebaek, Denmark.

Kjaer, E.D., E.B. Lauridsen and H. Wellendorf. 1995. Second evaluation of an International Series of Teak Provenance Trials, Danida Forest Seed Center, Humlebaek, Denmark.

Leksono, B. 2001. Workshop Nasional Jati 2001 Program Ilmu Kehutanan Universitas Sumatera Utara. Hotel Tiara, 4-6 September 2001. Pentingnya Benih Unggul dalam Program Penanaman Jati dan Strategi Pencapaiannya.

Palupi R. E. dan Murniati E. 1994. Studi Pendahuluan Pembungaan Jati (Tectona grandis L.) dan Hubungannnya dengan Produksi Benih. Website:http://lppm.ipb.ac.id/ID/index.php ?view=penelitian/hasilcari\&status $=$ buka \&id_haslit $=582.949++P A L++s$.

Diakses tanggal 25 November 2010.

Prosea, 1994. Plant Resources of South-East Asia 5; (1) Timber trees: Major commercials timbers, I.Soerianegara and R.H.M.J. Lemmens (Editors), PROSEA Foundation, Bogor, Indonesia, Page: 448-454.

Rachmawati, H., Djoko Irianto dan Christian P. Hansen. 2002. Tectona Grandis Linn. f. Informasi Singkat Benih Nomor 15 Januari 2002. Direktorat Perbenihan Tanaman Hutan.

Rivera, Eleena. Different Species of Teak Wood. Website :www.ehow.com/teak-wood/. Diakses tanggal 5 Agustus 2010.

Rudjiman,1991. New Species of Tectona, Prociding of International Seminar, Page 171-175

Sastrosumarto, S. dan Hendi Suhaendi, 1985. Tinjauan Mengenai Program Pemuliaan Jati (Tectona grandis Linn.f) di Indonesia,
Pusat Penelitian dan Pengembangan Hutan, Bogor.

Simatupang, Maruli H.,2000. Some Notes on Origin and Establishment of Teak Forest (Tectona grandis L.f.) in Java, Indonesia, Prociding Third Regional Seminar on Teak: Potentials and Opportunities in Marketing and Trade of Plantation Teak, Yogyakarta.

Singh, Gurcharan. 2004. Plant systematics: an integrated approach. USA : Science Publishers.

Subramanian, K.N., A. Nicodemus and A. Radhamani. 1994. Teak Improvement in India. Forest Genetic Resources Buletin No 22. V3965/E.Website:http://www.fao.org/docr ep/006/v3965e/V3965E13.htm. Diakses tanggal 2 Desember 2010

Tewari, D.N. 1992. A Monograph on Teak (Tectona grandis L. f.). International Book Distributors.

Tuntiwiwut, Manoonsak and Moonsarn, Suriyan. 2000, A History of Teak Forestry in Thailand, Prociding Third Regional Seminar on Teak: Potentials and Opportunities in Marketing and Trade of Plantation Teak, Yogyakarta.

Madulid, D.A., Agoo, E.M.G. \& Caringal, A.M. 2008. Tectona philippinensis. In: IUCN 2010. IUCN Red List of Threatened Species. Version 2010,. $<w w$ w.iucnredlist.org >. Downloaded on 26 May 2010.

Win, Zaw. 2009. Personal communication with Zaw Win, Myanmar Forest Product and Timber Mercants Association, Myanmar Forestry Department. 